\title{
Effect of the Stage of Sexual Cycle, Harvesting Technique and Season on Follicular Dynamics and Oocyte Quality of Zebu Cattle under Sudano-Sahelian Climate
}

\author{
Kouamo J*, Nono Fambo SM and Zoli AP \\ School of Veterinary Medicine and Sciences, The University of Ngaoundere, Ngaoundere, Cameroon \\ *Correspondence to: Justin Kouamo, School of Veterinary Medicine and Sciences, The University of Ngaoundere, Ngaoundere, Cameroon; Tel: +237 675376954; \\ Email: justinkouamo@yahoo.fr
}

Received: September 16, 2017; Accepted: September 25, 2017; Published: October 12, 2017;

\begin{abstract}
This study was carried out at the Ngaoundere Slaughterhouse (Adamawa region, Cameroon) on 353 normal cyclic zebu cows to investigate the effects of the stage of sexual cycle, harvesting technique and season on follicular dynamics and quality of cumulus-oocyte complexes (COCs). The stages of the sexual cycle were divided into estrus, metestrus, diestrus and proestrus. The oocytes were retrieved using the following techniques: slicing, aspiration, puncture, aspiration followed by slicing and puncture followed by slicing and classified into grades I, II, III and IV. The results indicated that the follicular population was $27.26 \pm 1.95$ follicles per cow. Oocytes recovery rate was $10.14 \pm 8.37$ per cow. The oocyte quality index and oocytes grade I and II acceptable for in vitro embryo production (IVEP) were 2.35 and $58.28 \%$, respectively. The stage of sexual cycle of cows has a significant effect $(\mathrm{P}<0.05)$ on the large follicles $(>8 \mathrm{~mm}$ ) but has no effect on the yield and oocytes quality. The rainy season offers a higher number of follicles and oocyte quality than the dry season. Slicing technique allows the best yield of oocyte acceptable for IVEP. The ascending hierarchical classification revealed that, to obtain the best rate of oocyte yield and quality, they should be retrieved in Gudali from the Vina by slicing or aspiration in the rainy season at estrus or metestrus stage, lower than 6 years old with a live weight of $368.53 \mathrm{~kg}$, body condition score of 3 and ovaries weight $>5 \mathrm{~g}$ with medium follicles ( 3 to $8 \mathrm{~mm}$ ).
\end{abstract}

Key words: follicular population, harvesting techniques, oocyte quality, season, stage of sexual cycle.

\section{Introduction}

The Adamawa region is an excellent pole for livestock (Bos indicus) in Cameroon. With more than $10 \%$ of the total bovine livestock [1], this region also represents the favorable area for convergence of the majority of bovine breeds present in the three northern region (Far North, Adamawa and North) and most of the cows are slaughtered at the municipal slaughterhouse of Ngaoundere. Despite the diversity of breeds, animal productivity remain low and is not enough to cover the demand of the population. For several years, the results of artificial insemination (AI) in sub-Saharan Africa and in Cameroon remains low, less than 30\% [2]. The problems could be either zootechnical, nutritional, sanitary or poor control of reproductive pathologies [3]. Assisted Reproductive Technologies (ARTs) such as AI, IVEP and multiple ovulation and embryo transfer (MOET) have been used to increase reproductive efficiency and accelerate genetic gain [4]. An intense interest exists internationally in investigating in vitro procedures for the maturation, fertilization, and culture of immature oocytes from domestic mammalian species. In cattle, IVEP is established as a commercial enterprise that includes the salvage of genetics from infertile females, as well as large-scale embryo production from slaughterhouse material [5]. The method of IVEP of embryos involves several steps: in vitro maturation of oocytes (IVM), in vitro fertilization of oocytes (IVF) with capacitated sperm and in vitro culture (IVC) of embryos up to blastocyst stage.
Collection of good-quality oocytes is the initial step for IVEP. The ovaries obtained at the slaughterhouse constitute the best source of affordable oocytes for large scale production of bovine embryos through IVM and IVF [6]. The follicular population and oocyte quality of local breeds depends on several factors such age, weight, body score condition, physiological status of the female, nutritional and pathological status $[3,7]$. What about the stage of the sexual cycle, the harvesting technique and the season in zebu (Bos indicus) rearing in tropical environment? It is in this context that this study was carried out with the main objective to evaluate the effects of stage of sexual cycle, collection technique and season on the follicular dynamic and oocyte quality in zebu cows. Specific objectives were to characterize the slaughtered zebu cows, determine the follicular population and oocyte quality and study the correlated effects between the characteristics of the cows, the stage of the sexual cycle, the harvesting technique and season on the follicular population and oocyte quality.

\section{Materials and Methods}

\section{Study area and animals characteristic}

The study was carried out in Ngaoundere, Adamawa region of Cameroon (Latitude $7^{\circ} 19^{\prime} 39^{\prime \prime} \mathrm{N}$ and Longitude13 $35^{\prime} 04^{\prime \prime} \mathrm{E}$ ), characterized by a sudano-sahelian climate. Average annual precipitations oscillate between 900 and $1500 \mathrm{~mm}$ with a short dry season of 4-5 months (November to March) and long rainy season 
of 7 to 8 months (April to October). The samples were collected at the Ngaoundere municipal slaughterhouse from August 2016 to June 2017 and analyzed in the Veterinary Research Laboratory of IRAD Wakwa.

353 cyclic local zebus of different breeds [Gudali (158), Djafoun (77), Akou (112) and Bokolo (6)] were randomly selected for this study. Cows were originated from the Mayo Rey (52.69\%) and Vina (47.31\%) division. The mean live weight was estimated from thoracic circumference (THC) as follows: $124.69-3.171 \mathrm{x}$ THC $+0.0276 \mathrm{x}$ $\mathrm{THC}^{2}$ [8]. Body condition score (BCS) and age of cows have been determined as described by $[9,10]$ Natumyana et al. and Moussa Garba et al. respectively.

\section{Determination of follicular population and stage of sexual cycle}

Ovaries (706) were obtained within $2 \mathrm{~h}$ from the Ngaoundere municipal slaughterhouse (NMSH) and were transported to the laboratory in a thermos flask containing sterile warm $\left(34-36^{\circ} \mathrm{C}\right)$ physiological normal saline solution (0.9\%) supplemented with antibiotics $(0.5 \mathrm{mg} / \mathrm{ml}$ penicillin-streptomycin sulfate). All ovaries were cleared off the attached tissue and mesovarium (trimming) and weighed using an electronic scale, Mettler PC 2000. The trimmed ovaries were subject to washings (5-6 times) with warm saline fortified with antibiotics and transferred into the laminar flow. The apparent follicles on each ovary were measured using an electronic Stainless Hardened caliper then counted and classified according to their diameter into small $(<3 \mathrm{~mm})$, medium $(3-8 \mathrm{~mm})$ and large $(>8 \mathrm{~mm})$ follicles [9]. Then the size and colour of corpus luteum present on the ovary were noted and permitted to distinguish four stages of the sexual cycle (proestrus, estrus, metestrus and diestrus) as described by Nguyen-Kien and Hanzen [11,12].

\section{Oocytes recovery}

Oocytes were harvested by five techniques in a graded plastic Petri dish containing oocyte collection medium (Dulbecco's phosphate-buffered saline): Aspiration [13] slicing [14] puncture aspiration+slicing [15] and puncture+slicing with an 18 Gauge needle. The collected oocytes were finally graded as excellent (I), good (II), fair (III), and poor (IV) quality under the stereo microscope $(\times 10)$ depending on their cumulus investment and cytoplasmic distribution [16]. The overall quality was calculated as an index using the formula $[(G$ I x $1+$ G II x $2+$ G III x $3+$ G IV x 4) / Total number of oocytes recovered] as described by Duygu et al. [17]. Index values that approache one reflected good quality oocytes.

Correlated effects of stage of sexual cycle, collection techniques, season and cow characteristics (origin, breed, body score condition, age, average ovary weight) on follicular population and oocyte quality

The correlation was realized by multiple correspondence analysis and 11 variables were retained: nine were nominal actives (origin, breed, age, BCS, mean weight of ovaries, stage of sexual cycle, season, collection technique, follicles) with two to five modalities and two were continuous illustrative variables (oocyte quality and cow weight). After the selection of these variables and their coding, the following analysis was carried out: multiple correspondence analysis, description of factorial axes, hierarchical ascending classification, tree break, class description and characterization of typology classes as recommended by Lebart et al. [18].

\section{Statistical analysis}

The collected data were analyzed using the Statfgraphic software plus version 5.0. The Wilcoxon and Kruskal-Wallis tests were used to compare different group. All the data were represented in mean \pm SEM (Standard Error of the Mean) and percentage at 5\% level of confidence.

\section{Results}

\section{Characterization of slaughtered cows}

The BCS and age (min- max) of animals were $2.80 \pm 0.04(2-4)$ and $6.56 \pm 2.34$ years (3-5), respectively. The mean weight of the ovaries was $1.91 \pm 0.07 \mathrm{~g}$ with $1.91 \pm 0.07 \mathrm{~g}$ and $1.80 \pm 0.07 \mathrm{~g}$ for the right and left ovaries, respectively. The mean weight (MW) of ovaries in \% (number) regrouped in classes [ $(\mathrm{I}<3 \mathrm{~g}),(3 \leq \mathrm{II} \leq 5 \mathrm{~g})$ and (III $>5 \mathrm{~g})$ ] were 29.75 (105), 49.29 (174) and 20.96 (74), respectively. The weight of cows significantly increases $(\mathrm{p}<0.05)$ with BCS. The right ovaries were heavier than the left one whenever the cow has a BCS $\geq 3$, aged more than 5 years and in the rainy season (Table 1).

\section{Follicular population}

Of the 706 ovaries collected, 9623 follicles were counted. The average total numbers of follicles per cow was 27.26 \pm 1.95 . Small $(<3 \mathrm{~mm})$, medium $(3-8 \mathrm{~mm})$ and large $(>8 \mathrm{~mm})$ follicles were $17.6 \pm 1.67$ (64.56\%), 9.18 \pm 0.88 (33.69\%) and $0.48 \pm 0.08$ (1.75\%) per cow, respectively. Only the season of the year has a significant effect $(\mathrm{P}<0.05)$ on the medium and large follicles as well as on the total follicular population. Follicles were more abundant in rainy than dry season (Table 2).

\section{Oocyte quality}

From 706 ovaries, 3581 oocytes were harvested. The mean oocyte yield per cow was $10.14 \pm 8.37$. The oocytes quality grade I, II, III and IV were $2.93 \pm 3.07$ (28.85\%), $2.98 \pm 3.08$ (29.41\%), $1.95 \pm 2.32$ (19.24\%) and $2.28 \pm 2.53(22.51 \%)$, respectively (Figure 1). The number

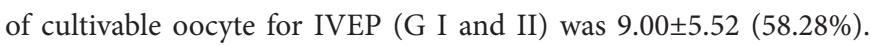
Oocyte index was 2.35. Slicing enables to collect a higher number of oocyte especially cultivable oocyte as compared to other techniques $(\mathrm{P}=0.00)$. The oocyte yield and quality, grade I and II were higher $(\mathrm{P}=0.00)$ in the rainy than dry season (Table 3$)$.

Correlated effects on the characteristics of cows (origin, race, BMI, average weight of ovaries), state of sexual cycle, harvesting technics and season on the follicular population and oocyte quality

From the hierarchical ascendant correspondence, two classes were identified as shown in Figure 2 following the factorial axe 1 and 2. Class 1 was constituted of Djafoun (38.59\%), Akou (58.15\%) and Bokolo breeds from the Mayo Rey (99.46\%); BCS 2- 4 ; 6-9 and 1015 years old; mean weight of ovaries $<3 \mathrm{~g}$ and $3-5 \mathrm{~g}$; sexual cycle in the stage of diestrus and proestrus; collection technique by puncture, aspiration-slicing, puncture-slicing; dry season (60.87\%); diameter of 
Justin Kouamo (2017) Effect of the Stage of Sexual Cycle, Harvesting Technique and Season on Follicular Dynamics and Oocyte Quality of Zebu Cattle under Sudano-Sahelian Climate

follicles $<3 \mathrm{~mm}$ and $>8 \mathrm{~mm}$. Class 2 was constituted of cows from Vina (98.24\%); Gudali breed (92.94\%); BCS 3 (85.29\%); 3-5 years old; average weight of ovary $>5 \mathrm{~g}$; sexual cycle in the stage of estrus and metestrus; harvesting technique by slicing (32.94\%) and aspiration; rainy season $(53.53 \%)$; mean diameter of follicles 3-8 $\mathrm{mm}$.

Table 1: Effects of origin, breed, BCS, age and season on weight of cows and ovaries (mean \pm SEM)

\begin{tabular}{|c|c|c|c|c|c|c|}
\hline Factors & & $\mathbf{N}$ & Mean weight of cows (Kg) & Left ovary Weight (g) & Right ovary Weight (g) & Ovary weight (g) \\
\hline \multirow[t]{3}{*}{ Origin of cows } & Mayo Rey & 186 & $362.11 \pm 3.98^{\mathrm{a}}$ & $1.72 \pm 0.10^{\mathrm{a}}$ & $1.91 \pm 0.11$ & $1.82 \pm 0.05$ a \\
\hline & Vina & 167 & $367.45 \pm 4.20^{\mathrm{a}}$ & $1.89 \pm 0.11^{b}$ & $2.05 \pm 0.11$ & $2.01 \pm 0.05^{b}$ \\
\hline & p-value & & 0.28 & 0.02 & 0.06 & 0.01 \\
\hline \multirow[t]{5}{*}{ Breed } & Gudali & 158 & $368.53 \pm 4.31^{\mathrm{a}}$ & $1.89 \pm 0.06^{\mathrm{a}}$ & $2.03 \pm 0.06^{\mathrm{a}}$ & $2.0 \pm 0.06^{\mathrm{a}}$ \\
\hline & Djafoun & 77 & $365.76 \pm 6.17^{\mathrm{a}}$ & $1.77 \pm 0.08^{\mathrm{a}}$ & $196 \pm 0.08^{\mathrm{a}}$ & $1.83 \pm 0.08^{\mathrm{a}}$ \\
\hline & Akou & 112 & $360.63 \pm 5.12^{\mathrm{a}}$ & $1.70 \pm 0.07^{\mathrm{a}}$ & $1.91 \pm 0.07^{\mathrm{a}}$ & $1.84 \pm 0.07^{\mathrm{a}}$ \\
\hline & Bokolo & 6 & $322.39 \pm 22.10^{\mathrm{a}}$ & $1.67 \pm 0.29^{\mathrm{a}}$ & $2.0 \pm 0.30^{\mathrm{a}}$ & $2.0 \pm 0.30^{\mathrm{a}}$ \\
\hline & p-value & & 0.11 & 0.21 & 0.61 & 0.19 \\
\hline \multirow[t]{4}{*}{ BCS } & Thin [1-2] & 70 & $342.67 \pm 6.38$ a & $1.54 \pm 0.08^{\text {a }}$ & $1.76 \pm 0.09$ a & $1.66 \pm 0.08 \mathrm{a}$ \\
\hline & Good [3] & 282 & $370.02 \pm 3.18^{b}$ & $1.87 \pm 0.04 \mathrm{~b}$ & $2.0 \pm 0.04 \mathrm{~b}$ & $1.98 \pm 0.04$ b \\
\hline & Fat [4-5] & 1 & $383.26 \pm 53.34 \mathrm{a}, \mathrm{b}$ & $1.0 \pm 0.70 \mathrm{a}, \mathrm{b}$ & $2.0 \pm 0.73 \mathrm{a}, \mathrm{b}$ & $2.0 \pm 0.7 \mathrm{a}, \mathrm{b}$ \\
\hline & $p$-value & & 0.00 & 0.00 & 0.02 & 0.00 \\
\hline \multirow[t]{4}{*}{ Age (Years) } & [3-5] & 161 & $361.77 \pm 4.29^{\mathrm{a}}$ & $1.65 \pm 0.06^{\mathrm{a}}$ & $1.8 \pm 0.06^{\mathrm{a}}$ & $1.76 \pm 0.05$ a \\
\hline & [6-9] & 147 & $368.1 \pm 4.48^{\mathrm{a}}$ & $1.96 \pm 0.06^{b}$ & $2.06 \pm 0.06^{b}$ & $2.03 \pm 0.06^{\mathrm{b}}$ \\
\hline & {$[10-15]$} & 45 & $363.59 \pm 8.11^{\mathrm{a}}$ & $1.82 \pm 0.10 \mathrm{a}, \mathrm{b}$ & $2.18 \pm 0.11^{b}$ & $2.07 \pm 0.10^{\mathrm{b}}$ \\
\hline & p-value & & 0.56 & 0.00 & 0.01 & 0.00 \\
\hline \multirow[t]{3}{*}{ Season } & Rainy & 162 & $369.43 \pm 4.26^{\mathrm{a}}$ & $1.93 \pm 0.11^{\mathrm{a}}$ & $2.07 \pm 011^{\mathrm{a}}$ & $2.03 \pm 0.06^{\mathrm{a}}$ \\
\hline & Dry & 191 & $360.57 \pm 3.92^{\mathrm{a}}$ & $1.69 \pm 0.1^{\mathrm{b}}$ & $1.90 \pm 0.10^{\mathrm{b}}$ & $1.81 \pm 0.05 \mathrm{~b}$ \\
\hline & p-value & & 0.05 & 0.00 & 0.03 & 0.00 \\
\hline
\end{tabular}

a,b,c : In each column different letters indicated significant difference between group $(\mathrm{p}<0.05)$. N=number of cows. $\mathrm{SE}=$ standard error

Table 2: Population and follicular size following the stage of the sexual cycle and season (mean \pm SEM)

\begin{tabular}{|c|c|c|c|c|c|c|}
\hline \multirow[b]{2}{*}{ Factors } & & \multirow[b]{2}{*}{$\mathbf{N}$} & \multicolumn{3}{|c|}{ Number of follicles } & \multirow[t]{2}{*}{ Average number of follicles } \\
\hline & & & $\underset{(<3 \mathrm{~mm})}{\text { Small }}$ & $\begin{array}{l}\text { Medium } \\
\text { (3-8mm) }\end{array}$ & $\begin{array}{c}\text { Large } \\
(>8 \mathrm{~mm})\end{array}$ & \\
\hline \multirow[t]{5}{*}{ Stage of the sexual cycle } & Metestrus & 9 & $11.33 \pm 5.29^{\mathrm{a}}$ & $12.00 \pm 2.79^{\mathrm{a}}$ & $1.22 \pm 0.25 \mathrm{a}, \mathrm{b}$ & $24.56 \pm 6.21^{a}$ \\
\hline & Diestrus & 164 & $18.14 \pm 1.24$ a & $10.26 \pm 0.65$ a & $0.37 \pm 0.06^{c}$ & $28.77 \pm 1.45$ a \\
\hline & Proestrus & 148 & $18.49 \pm 1.30^{\mathrm{a}}$ & $8.24 \pm 0.69$ a & $0.36 \pm 0.06^{c, d}$ & $27.09 \pm 1.53^{\mathrm{a}}$ \\
\hline & Estrus & 32 & $12.5 \pm 2.81^{\mathrm{a}}$ & $8.24 \pm 0.69^{a}$ & $1.34 \pm 0.13$ a & $21.09 \pm 3.29^{\mathrm{a}}$ \\
\hline & $\mathrm{p}$-value & & 0.14 & 0.27 & 0.00 & 0.21 \\
\hline \multirow[t]{3}{*}{ Season } & Rainy & 162 & $17.78 \pm 2.72 \mathrm{a}^{\mathrm{a}}$ & $11.34 \pm 1.42$ a & $0.67 \pm 0.15$ a & $29.8 \pm 3.21$ a \\
\hline & Dry & 191 & $17.45 \pm 2.07 \mathrm{~b}$ & $7.36 \pm 1.04 \mathrm{~b}$ & $0.31 \pm 0.08^{b}$ & $25.11 \pm 2.35^{b}$ \\
\hline & $\mathrm{p}$-value & & 0.65 & 0.00 & 0.00 & 0.03 \\
\hline
\end{tabular}

a,b,c,d : In each column different letters indicated significant difference between group $(\mathrm{p}<0.05)$. N=number. 


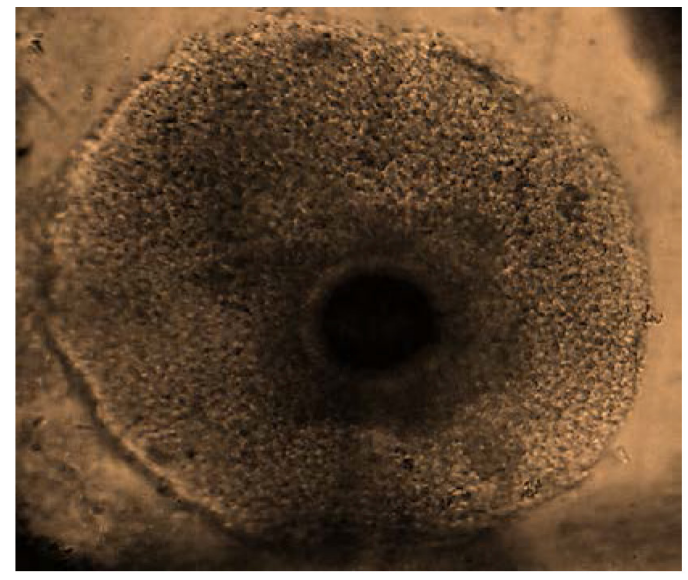

(a)

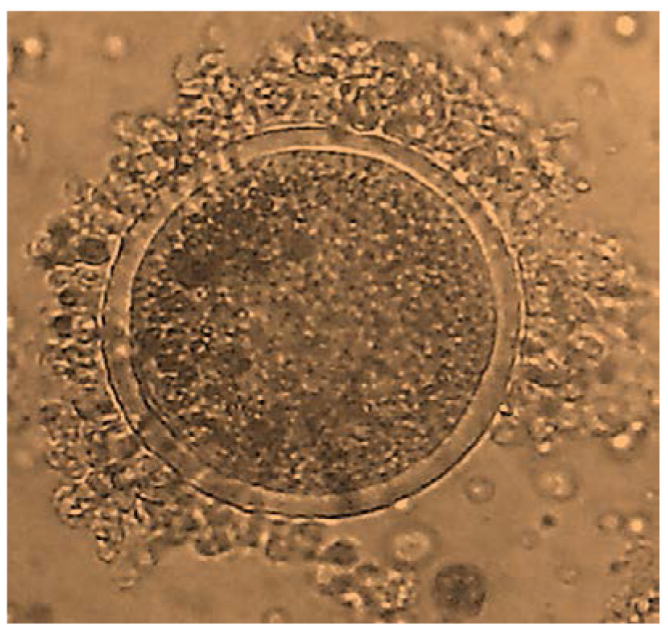

(c)

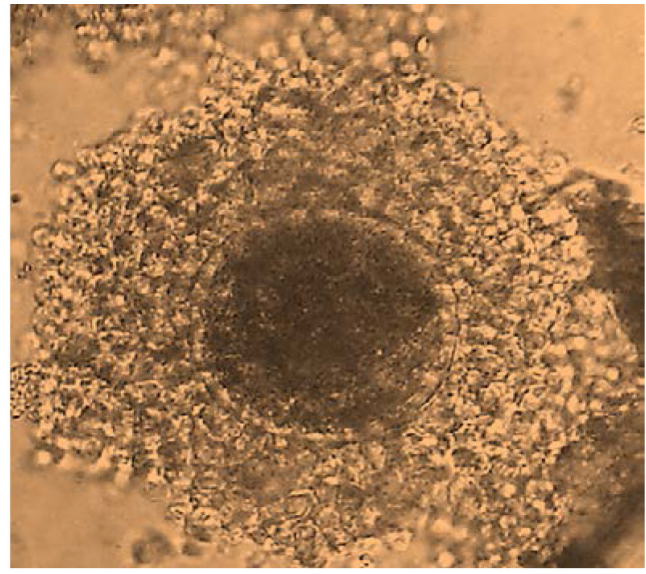

(b)

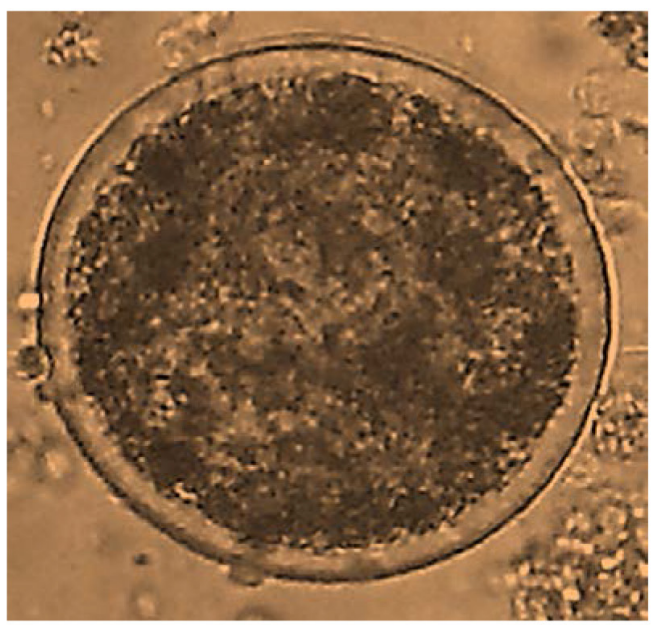

(d)

Figure 1: oocyte quality: (a) grade I ; (b) grade II ; (c) grade III ; (d) grade IV.

Table 3: Effect on the stage of sexual cycle, harvesting techniques and season on the yield and oocyte quality (Mean $\pm \operatorname{SEM})$

\begin{tabular}{|c|c|c|c|c|c|c|c|c|}
\hline \multicolumn{9}{|c|}{ Oocyte grades } \\
\hline Factors & & $\mathbf{N}$ & $\begin{array}{c}\text { Average } \\
\text { number of oocytes }\end{array}$ & I & II & III & IV & $\begin{array}{l}\text { Selected oocytes for } \\
\text { IVEP. I and II (\%) }\end{array}$ \\
\hline \multirow{5}{*}{$\begin{array}{l}\text { Stage of the } \\
\text { sexual cycle }\end{array}$} & Metestrus & 9 & $12.56 \pm 2.79 \mathrm{a}$ & $3.00 \pm 1.03 \mathrm{a}$ & $3.67 \pm 1.03$ a & $2.89 \pm 0.77$ a & $3.00 \pm 0.84{ }^{\mathrm{a}}$ & $6.67 \pm 1.85^{\mathrm{a}}(53.1)$ \\
\hline & Diestrus & 164 & $10.47 \pm 0.65^{\mathrm{a}}$ & $2.77 \pm 0.24^{\mathrm{a}}$ & $3.08 \pm 0.24^{\mathrm{a}}$ & $2.07 \pm 0.18^{\mathrm{a}}$ & $2.50 \pm 0.20^{\mathrm{a}}$ & $5.85 \pm 0.43^{\mathrm{a}}(56.14)$ \\
\hline & Proestrus & 148 & $10.16 \pm 0.69$ a & $3.18 \pm 0.25$ a & $2.94 \pm 0.25$ a & $1.93 \pm 0.19$ a & $2.12 \pm 0.21^{\mathrm{a}}$ & $6.11 \pm 0.46 \mathrm{a}(60.17)$ \\
\hline & Estrus & 32 & $7.94 \pm 1.48$ a & $2.53 \pm 0.54$ a & $2.50 \pm 0.55$ a & $1.19 \pm 0.41 \mathrm{a}$ & $1.79 \pm 0.45^{\mathrm{a}}$ & $5.03 \pm 0.98$ a $(63.39)$ \\
\hline & p-value & & 0.42 & 0.24 & 0.57 & 0.10 & 0.43 & 0.55 \\
\hline \multirow{3}{*}{$\begin{array}{l}\text { Harvesting } \\
\text { technique }\end{array}$} & Slicing & 83 & $15.61 \pm 0.83 \mathrm{a}$ & $4.67 \pm 0.31$ a & $4.80 \pm 0.32 \mathrm{a}$ & $2.88 \pm 0.24$ a & $3.27 \pm 0.27 \mathrm{a}$ & $9.47 \pm 0.55$ a $(60.65)$ \\
\hline & Puncture & 85 & $7.28 \pm 0.82 \mathrm{~b}, \mathrm{e}$ & $2.18 \pm 0.30 \mathrm{~b}$ & $2.19 \pm 0.31 \mathrm{e}, \mathrm{b}$ & $1.3 \pm 0.24 \mathrm{~b}, \mathrm{~d}$ & $1.67 \pm 0.26^{\mathrm{b}, \mathrm{d}}$ & $4.31 \pm 0.54$ b $(59.13)$ \\
\hline & Aspiration & 81 & $5.77 \pm 0.84 \mathrm{c}, \mathrm{b}$ & $1.23 \pm 0.31^{\mathrm{c}}$ & $1.77 \pm 0.32 \mathrm{c}, \mathrm{b}$ & $1.32 \pm 0.25 \mathrm{c}, \mathrm{b}$ & $1.44 \pm 0.27 \mathrm{c}, \mathrm{b}$ & $3.00 \pm 0.56 \mathrm{c}, \mathrm{b}(52.03)$ \\
\hline
\end{tabular}


Justin Kouamo (2017) Effect of the Stage of Sexual Cycle, Harvesting Technique and Season on Follicular Dynamics and Oocyte Quality of Zebu Cattle under Sudano-Sahelian Climate

\begin{tabular}{|l|l|c|c|c|c|c|c|c|}
\hline & $\begin{array}{l}\text { Aspiration }+ \\
\text { Slicing }\end{array}$ & 80 & $11.94 \pm 0.84^{\mathrm{d}}$ & $3.49 \pm 0.31 \mathrm{~d}$ & $3.13 \pm 0.32 \mathrm{~d}$ & $2.48 \pm 0.25^{\mathrm{a}}$ & $2.85 \pm 0.27 \mathrm{a}, \mathrm{e}$ & $6.61 \pm 0.56 \mathrm{~d}(55.39)$ \\
\hline & $\begin{array}{l}\text { Puncture }+ \\
\text { Slicing }\end{array}$ & 24 & $10.17 \pm 1.53 \mathrm{e}, \mathrm{d}$ & $3.58 \pm 0.57 \mathrm{a}, \mathrm{d}$ & $3.17 \pm 0.59 \mathrm{e}, \mathrm{d}$ & $1.42 \pm 046 \mathrm{~d}, \mathrm{c}$ & $2.00 \pm 0.50 \mathrm{~d}, \mathrm{c}, \mathrm{e}$ & $6.75 \pm 1.02 \mathrm{e}, \mathrm{d}(66.39)$ \\
\hline & P-value & & 0.00 & 0,00 & 0,00 & 0.00 & 0.00 & 0.00 \\
\hline Season & Rainy & 162 & $11.91 \pm 1.41^{\mathrm{a}}$ & $3.01 \pm 0.44^{\mathrm{a}}$ & $3.34 \pm 0.48^{\mathrm{a}}$ & $2.54 \pm 0.43 \mathrm{a}$ & $3.01 \pm 0,46^{\mathrm{a}}$ & $6.35 \pm 0.82^{\mathrm{a}}(53.34)$ \\
\hline & Dry & 191 & $8.65 \pm 1.05^{\mathrm{b}}$ & $2.85 \pm 0.46^{\mathrm{a}}$ & $2.68 \pm 0.44^{\mathrm{b}}$ & $1.45 \pm 0.24 \mathrm{~b}$ & $1.66 \pm 0.27 \mathrm{~b}$ & $5.53 \pm 0.81^{\mathrm{b}}(53.98)$ \\
\hline & p-value & & 0.00 & 0.19 & 0.00 & 0.00 & 0.00 & 0.03 \\
\hline
\end{tabular}

a, b, c, d, e $:$ In each column different letters indicated significant difference between group $(\mathrm{p}<0.05)$. $\mathrm{N}=$ number.

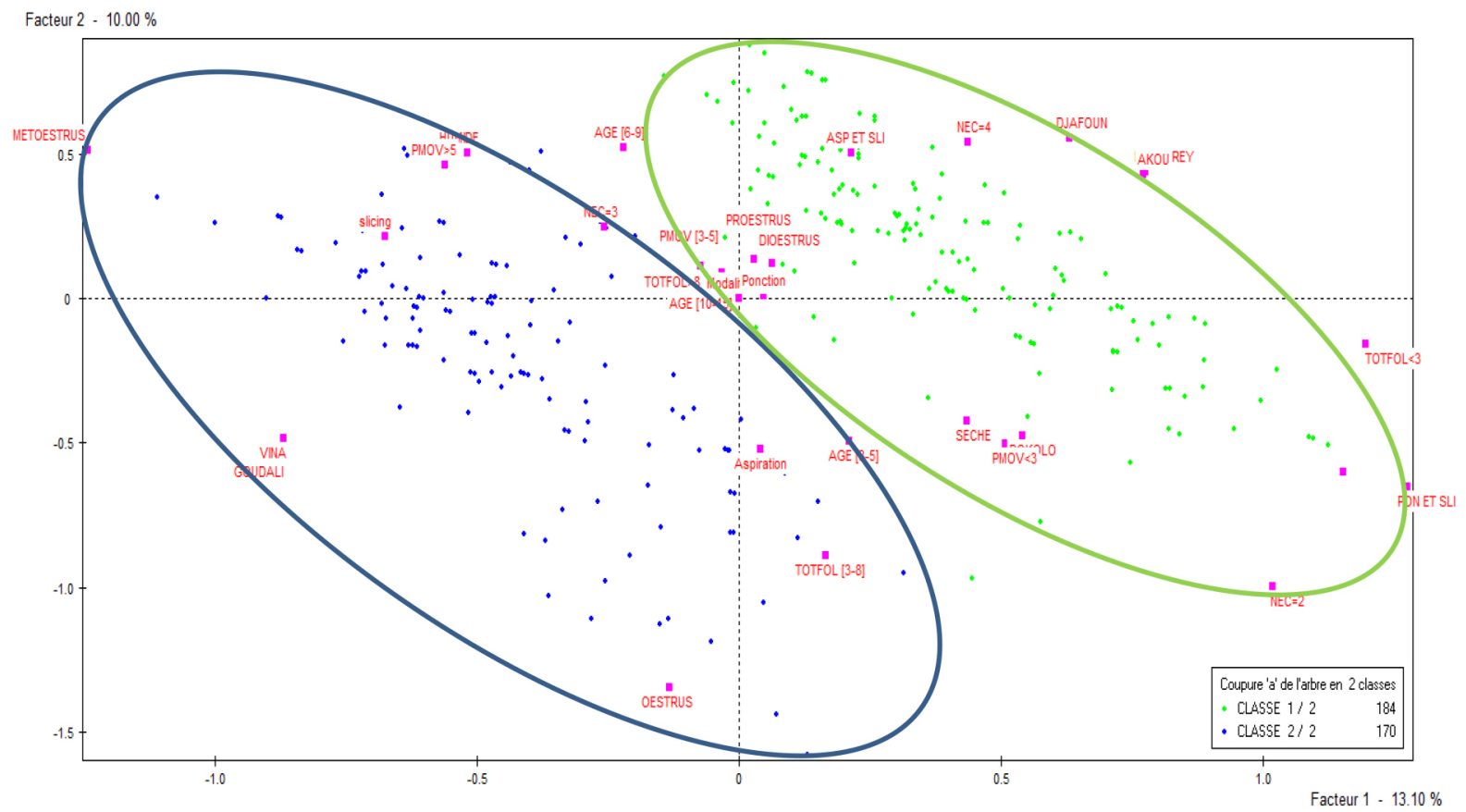

Figure 2: Distribution of the two classes representing the individuals in a factorial plan 1 and 2.

Table 4: Variation of the total follicles, yield and oocyte quality per cow the two classes (Mean \pm SEM)

\begin{tabular}{|c|c|c|c|c|c|c|c|c|c|}
\hline \multirow[b]{2}{*}{ Factors } & \multirow[b]{2}{*}{$\mathbf{N}$} & \multirow[b]{2}{*}{$\begin{array}{c}\text { Mean weight } \\
\text { of cows } \\
(\mathrm{Kg})\end{array}$} & \multirow[b]{2}{*}{$\begin{array}{c}\text { Average } \\
\text { number of } \\
\text { follicles }\end{array}$} & \multirow[b]{2}{*}{$\begin{array}{c}\text { Average } \\
\text { number of } \\
\text { oocytes }\end{array}$} & \multicolumn{4}{|c|}{ Oocytes grades } & \multirow{2}{*}{$\begin{array}{c}\text { Selected oocytes } \\
\text { for } \\
\text { IVEP. I and II } \\
\text { (\%) }\end{array}$} \\
\hline & & & & & I & II & III & IV & \\
\hline Classe I & 183 & $349.59 \pm 11.13$ & $29.00 \pm 19.00$ & $8.50 \pm 7.00$ & $2.41 \pm 2.66$ & $2.46 \pm 2.64$ & $1.66 \pm 2.13$ & $1.97 \pm 2.32$ & $4.87 \pm 5.30(57.3)$ \\
\hline Classe II & 170 & $368.53 \pm 4.31$ & $26.00 \pm 18.00$ & $11.91 \pm 9.00$ & $3.48 \pm 3.37$ & $3.54 \pm 3.42$ & $2.27 \pm 2.47$ & $2.62 \pm 2.67$ & $7.02 \pm 6.79(59.00)$ \\
\hline $\mathrm{P}$ - value & & 0.10 & 0.12 & 0.75 & 0.52 & 0.61 & 0.92 & 0.68 & 0.17 \\
\hline
\end{tabular}

The class $2(\mathrm{n}=170 ; 48.02 \%)$ presents a better yield and oocyte quality than class $1(\mathrm{n}=183 ; 51.98 \%)$ as illustrated in Table 4 .

\section{Discussion}

\section{Follicular population}

The average follicular population counted on the surface of ovaries was similar to those obtained by Carvalho, et al. [19] on Nellore Zebus and inferior in Moroccan zebus [20]. The high number of small follicles is due to the high numbers of reserve follicles recruited to evolve until one arrives the stage of dominant follicle. Cows of class 1 have mostly small $(<3 \mathrm{~mm})$ and large $(>8 \mathrm{~mm})$ follicles whereas those of class 2 have more medium (3-8mm) follicles. The differences might be due to several factors which constitutes each class like the stage of sexual cycle. In this study, many follicles were observed during diestrus and proestrus (class1) than metestrus and estrus (class 2). 
A high number of punctured follicles was reported at the onset of the cycle (4.9) than the middle (3.4) or the end (3.9) [12]. In estrus stage, the follicles are large in size and only one becomes dominant $(12-13 \mathrm{~mm})$ while the others are atresia [21]. This might explain the fact that more large follicles were observed in estrus stage in this study. The higher number of follicles accounted on the ovary in the rainy season was reported by Fassi Fihiri [19] and Amer and Moose [22] who indicated that ovarian activity is better in the rainy season (class 2). The reproductive performance in the dry season is low and affects the follicular growth due to thermic stress [23, 24]. Barati et al and Al-katanani et al. explained that heat increase the number of small follicles as we observed in class 1 of this study and transferable embryos are in bad quality [25]. Armstrong [26] reported that fertility of all species reduce with age. This is in accordance with this study where the number of follicles reduce with age. Older cows in the dry season are lighter in weight due to the scarcity of forage and their ovaries are less heavy $(<5 \mathrm{~g})$ as in the class 1 [27].

\section{Oocyte quality}

The oocyte yield and quality are similar to those obtained by Mutha and Uma [28] and superior to that reported by several authors $[9,26$, 29]. The difference might be due to the harvesting techniques and other factors (breed, age, BCS, weight of ovary and the origin of the cow). Different factors between class 1 and 2 explained the variation of the oocyte production. The number of oocytes graded I, II, III and IV as well as cultivated oocytes (I and II) reduces in class 1 with respect to the global population compared to class 2 . The best quality of oocyte is obtained from follicles with average size and there is a linear growth relationship between the diameter of oocytes and the size of ovarian follicle [30]. Acceptable oocytes for IVM (G I and II) are in the interval of 30 to $60 \%$ oocytes as reported by Natumyana et al. [9]. Considering the multifactorial analysis, metestrus and estrus (class 2) offers a better yield and quality oocytes than proestrus and diestrus (class 1). Hanzen [11] reported that the level of oocytes recovered (50 and $53 \%$ ) is the same at all the stages of the sexual cycle. Meanwhile Mutha and Uma [28] showed that the oocyte yield and the quantity of cultivable oocytes are greater when the cows are in the follicular (proestrus and estrus) than (metestrus and diestrus) luteal stage. At the onset of the sexual cycle of the cow, numerous reserve follicles are continuously recruited to develop to the stage of De Graafian follicles. Thus, estrus and metestrus constitute the favourable period of the sexual cycle for the emergence of quality oocytes.

The oocyte yield and quality as well as the cultivable oocytes (I and II) are higher using the slicing technique compared to others (class 2). These results are similar to those obtained by several authors Das and Santra Mutha and Uma, Bohlooli et al.,) $[31,28,15]$. The slicing technique collects free oocytes at the surface as well as the cortex from ovaries. Moreover, certain oocytes lost by the aspiration and puncture methods can be recovered by slicing and could increase the quantity of retrieved oocytes [15]. The low yield of oocyte collected by aspiration may be due to the method which retrieves only the superficial follicles and to the pressure applied by aspiration as well as the size of the needles [32]. In an experiment in which recovered oocytes were cultured to blastocysts, Wikland et al. [33] showed that the percentage of recovered oocytes that became blastocysts decreased as pressure increased. Fry et al. [34] aspirated 5827 follicles from 720 ovaries with 17 and 20-gauge needles. More than 5000 of these follicles were 2-4 $\mathrm{mm}$ in diameter. The rest were 5-15 $\mathrm{mm}$. With 17 -gauge needles, $56 \%$ of the follicles yielded oocytes, but with 20-gauge needles, recovery dropped to $45 \%$. The highest recovery also occurred with the highest aspiration pressures. The pressures evaluated ranged from 25 to $100 \mathrm{~mm} \mathrm{Hg}$. Recovery was $46 \%$ at $25 \mathrm{~mm} \mathrm{Hg}$ and $59 \%$ at $100 \mathrm{~mm}$ Hg. They concluded that the optimal pressure to maximize recovery of bovine COCs was $55 \mathrm{~mm} \mathrm{Hg}$ with a 17-gauge needle and $77 \mathrm{~mm}$ $\mathrm{Hg}$ for a 20-gauge needle. As aspiration pressures increased, the recovered oocytes were increasingly denuded of cumulus cells [35]. This loss of cumulus cells also occurred at lower aspiration machine pressures using larger diameter needles compared to smaller diameter needles, suggesting that needle gauge and pressure interdependently contributed to outcome. Dominguez [36] and Fassi Fihri [7] noted a significant difference in terms of oocyte yield in the European and zebu breeds as well as crossbreeds. Gudali breeds from the Vina division, of at least 6 years old during estrus and metestrus associated with other factors like slicing or aspiration techniques in the rainy season offers a better oocyte yield (class 2). This finding confirms the adaptability of the Gudali breed in its natural environment (class 2). Moreover, Natumanya et al. [9] reported that oocyte yield and quality are reduced in tropical zebus aged more than 10 years, thin (BCS 1 and 2 ) and having small ovaries $(<5 \mathrm{~g})$ (class 1$)$.

Ovarian activity was best in the rainy season [22]. The rainy season allows emergency of medium follicles (class 2). The slicing technique, when practiced in the rainy season (class 2), optimises the oocyte yield $[36,22]$. Kubovicova et al. [47] obtained a high oocyte yield when the cows had an average BCS (class 2). They confirmed that the nutritional status of the animal had an influence on the ovarian function in zebu cows, likewise the season of the year [37]. In fact, there is abundant and quality pasture in rainy season resulting in well fed cows. The metabolic and hormonal changes between the rainy and dry season affect follicular dynamics and oocyte development. During oogenesis and folliculogenesis, several dynamic processes that are regulated by endocrine, paracrine and autocrine signals have been shown to be linked with energetic status and the quality of oocyte depends on the nutritional condition under which the follicle began its development [38]. Moreover, ooocyte growth and maturation are believed to be particularly sensitive to changes in nutritional, chemical, and endocrine environments.

This study indicates that the oocyte yield and quality are high when they are retrieved in class 2 conditions. To improve the IVEP, it is recommended to harvest the oocytes in zebu cattle by slicing in the rainy season at estrus or metestrus.

\section{Acknowledgements}

The authors acknowledge contribution of NMSH.

\section{References}

1. MINEPIA (Ministry of Livestock, Fisheries and Animal Husbandry) (2009). Schéma directeur pour le développement des filières de l'élevage au Cameroun, volume II: cartographie des filières. 82. 
2. Kouamo J, Sow A Leye A, Sawadogo GJ and Ouedraogo GA (2009) Amélioration des performances de production et de reproduction des bovins par l'utilisation de l'insémination artificielle en Afrique Sub-saharienne et au Sénégal en particulier: état des lieux et perspectives. RASPA 7: 139-148.

3. Kouamo J, Meyoufey B and Zoli AP (2016) Pathological study of female reproductive organs of local zebus in Adamawa region. Bull Anim Hlth Prod Afr 64: $119-128$.

4. Manik RS, Singla SK and Palta P (2003) Collection of oocytes through transvaginal ultrasound-guided aspiration of follicles in an Indian breed of cattle. Anim Reprod Sci 76: $155-161$.

5. Abraham MC, Gustafsson H, Ruete A, Brandt YC (2012) Breed influences on in vitro development of abattoir-derived bovine oocytes. Acta Vet Scan 54: 1-6.

6. Agrawal KP, Sharma T, Sexana C and Sharma N (1995) Chronology of first meiotic events of caprine oocytes matured in vitro. Indian J Anim Sci 65: 285-288.

7. Fassi Fihri AH, Lakhdissi L, Derqaoui Kh, Hajji M, Naciri A and Goumari (2005) Genetic and non-genetic effects on the number of ovarian follicles and oocyte yield and quality in the bovine local (Oulmes Zaer), exotic breeds and their crosses in Morocco. African J Biotech 4: 9-13.

8. Njoya A, Bouchel D, Ngo Ntama AC, Moussa CA, Martrenchar A and Leteneur L (1997). Systèmes d'élevage et productivité des bovins en milieu paysan au nordCameroun. World Anim Review 89: 12-23.

9. Natumanya R, Owiny D and Kugonza R (2008) The potential of Ankole cattle abattoir ovaries for in vitro embryo production. African J Anim Biomed Sci 3: 1-5.

10. Moussa Garba MH, Marichatou M, Issa ML, Abdoul Aziz C and Hanzen C (2013) Tractus génital des vaches zébus (Bos indicus) au Niger Rev Elev Med Vet Pays Trop 66: 137-142

11. Hanzen C (2009) La production d'embryons in vitro. 21: 3.

12. Satrapa RA, Nabhan T, Silva CF, Simoens RAL, Razza EM, et al. (2010). In?uence of sire breed (Bos indicus versus Bos taurus) and interval from slaughter to oocyte aspiration on heat stress tolerance of in vitro-produced bovine embryos. Theriogenology 76: 1162-1167.

13. Nguyen-Kien C and Hanzen C (2009) Ante mortem and post mortem examination of the genital tract of dairy cows in South Vietnam Rev Elev Med Vet Pays Trop 66: 85-90.

14. Wang ZG, Song-Dong Y and Zi-Rong X (2007) Effects of collection methods on recovery efficiency, maturation rate and subsequent embryonic developmental competence of oocytes in holstein cow. Asian-Aust J Anim Sci 20: 496-500.

15. Bohlooli BS and Cedden F (2015) Effect of Different Harvesting Techniques on the Recovery and Quality of Bovine Cumulus Oocyte Complexes. Iranian J Applied Anim Sci 5: 741-74.

16. Alves BG, Alves KA, Lucio AC, Martins, MC and Silvas TH (2014) Ovarian activity and oocyte quality associated with the biochemical profil of serum and follicular fluid from girolando dairy cows postpartum. Anim Reprod Sci 146: 89236.

17. Duygu BA, Muhammed KB, Dogan N and Hander G (2013) Effect of the stage of oestrus cycle on follicular population oocyte yield and quality, and biochemical composition of serum and follicular fluid in Anatolian water buffalo. Anim Repro Sci 137: 8-114.

18. Lebart L, Morineau A and Piron M (2000) Statistique exploratoire multidimensionnelle. DUNOD 3e éd 439.

19. Carvalho JB, Carvalho NA, Reis EL, Nichi M, Souza AH and Baruselli PS (2008) Effect of early luteolysis in progesterone-based timed ai protocols in bos indicus, bos indicus $\mathrm{x}$ bos taurus, and bos taurus heifers. Theriogenology 69: 167-175

20. Fassi Fihri A (2006) Collecte et maturation des ovocytes bovins: Effet de l'état nutritionnel sur le rendement et la qualité des ovocytes. Thèse de Doctorat d'Etat Es-Sciences Biologiques 163.

21. Fieni F, Tainturuer D, Bruyas JF and Battut I (1998). Examen échotomographique des ovaires chez la vache. Journées nationales des GTV 411-415.

22. Amer H and Moose A (2008) Relationship between season of the year, culture medium and in vitro oocyte competence in dromedary camels. Bulg J Vet Med 11: 195-204.

23. Barati F, Niasari-naslaji A, Bolourchi A, Sarhaddi F, Razavi K, et al. (2006) Superovulatory response of Sistani cattle to three different doses of FSH during winter and summer. Theriogenology 66: 1149-1155.

24. Al-Katanani YM1, Paula-Lopes FF, Hansen PJ (2002) Effect of season and exposure to heat stress on oocyte competence in Holstein cows. J Dairy Sci 85: 390-396. [crossref]

25. Taneja M, Totey SM and Ali A (1995). Seasonal variation in follicular dynamics of superovulated Indian water buffalo. Theriogenology 43: 451-464.

26. Armstrong DT (2001) Effects of maternal age on oocyte developmental competence. Theriogenology 55: 1303-1322. [crossref]

27. Nandi S, Chauhan MS and Palta P (2001) Effect of environmental temperature on quality and developmental competence in vitro of buffalo oocytes. Vet Record 148: $278-279$.
28. Mutha RM and Uma MY (2012) Efficacy of different harvesting techniques on oocyte retrieval from buffalo ovaries. Buffalo Bulletin 31: 4 .

29. Zheng-Guang W, Song-Dong Yu and Zi-Rong X (2007) Effects of Collection Methods on Recovery Efficiency, Maturation Rate and Subsequent Embryonic Developmental Competence of Oocytes in Holstein Cow. Asian-Aust. J Anim Sci 20: 496-500

30. Yadav EN, Kharche SD, Goel AK, Jindal SK and Johri DK (2007) Comparative efficacy of different techniques for oocytes recovery from pre pubertal goat ovaries. Indian J Anim Sci 77: 988-990.

31. Das SK and Santra A (2008) Comparative the efficiency of different oocyte recovery methods from cattle ovaries. Indian J Anim Sci 78: 277-278.

32. Maina VA, Muktar A and Sabo YG (2008). Effects of Body Condition Score on ovarian activity of Bos indicus (Zebu) Cow. Asian J Sci Res 1: 421-428.

33. Wikland M, Blad S, Bungum L, Hillensjö T, Karlström PO (2011) A randomized controlled study comparing pain experience between a newly designed needle with a thin tip and a standard needle for oocyte aspiration. Hum Reprod 26: 1377-83.

34. Fry RC, Niall EM, Simpson TL, Squires TJ, Reynolds J (1997) The collection of oocytes from bovine ovaries. Theriogenology 47: 977-987. [crossref]

35. Bols PE, Ysebaert MT, Van Soom A and de Kruif A (1997). Effects of needle tip bevel and aspiration procedure on the morphology and developmental capacity of bovine compact cumulus oocyte complexes. Theriogenology 47: 1221-36.

36. Davachi DN, Shahneh Zare A, Kohram H, Zhandi M, Dashti S, et al. (2014). In Vitro Ovine Embryo Production: the Study of Seasonal and Oocyte Recovery Method Effects. Iran Red Crescent Med J 16 (9): e20749.

37. Ali S, Ahmad N, Akhtar N, Zia-ur R and Sarwar M (2007) Effect of season and age on the ovarian size and activity of one-humped camel (Camelus dromedarius). Asian-Aus J Anim Sci 20: 1361-1366.

38. Monniaux D, Caraty A, Clement F, Dalbiès-Tran R, Dupont J, et al. (2009) Développement folliculaire ovarien et ovulation chez les mammifères. Inra Prod Anim 22: 59- 76.

\section{Citation:}

Justin Kouamo, Nono Fambo SM and Zoli AP (2017) Effect of the Stage of Sexual Cycle, Harvesting Technique and Season on Follicular Dynamics and Oocyte Quality of Zebu Cattle under Sudano-Sahelian Climate. Integr J Vet Biosci Volume 1(1): 1-7 